\title{
Federal vs. State Roads: Assessing the Influence of Intergovernmental Relations Models on Road Maintenance in Nigeria
}

\author{
Silk. Ugwu Ogbu and Fred Ezeh
}

\begin{abstract}
The study examined the influence of intergovernmental relations, specifically, in terms of relations between the federal and state governments on road maintenance in Nigeria. The motivation for the study was the deplorable condition of several Nigerian roads which has been largely attributed to role conflicts between the two tiers of government. The influence of three types of inter-governmental relation (Partnership, Principal/Agent and Dual Functionalism models) on road maintenance was examined. The study conveniently drew its sample from staffs of federal and state ministry of works as well as staffs of the Federal Road Maintenance Agency (FERMA) in Enugu State. Data were collected using a five-point Likert scale questionnaire. The reliability of the instrument was ascertained by means of Cronbach Alpha which gave a coefficient of 72 percent. The data obtained were analyzed using frequency, percentages and multiple linear regression analysis. The findings revealed that the partnership model and functional dualism model of intergovernmental relations significantly influence road maintenance in Nigeria. It was recommended that all levels of government should strive to adopt the partnership or functional dualism model of intergovernmental relations. This would enable them to cooperate rather than compete, knowing that they are all partners in national progress.
\end{abstract}

Index Terms-Inter-Governmental Relations, Functional Competence, Federalism, Partnership, Fiscal Relations, InterDependence, Transparency, Accountability.

\section{INTRODUCTION}

Basically, there are three tiers of government in Nigeria with clearly defined roles. These roles are contained in legislative lists. The items contained in the exclusive legislative list are exclusively for the federal government; those in the concurrent legislative list could be undertaken by the federal and state governments; while those in the residual list are under the jurisdiction of states and local governments. The provision of road infrastructure falls under the purview of the concurrent legislative list and hence can be embarked upon by both the federal and state governments.

Intergovernmental relations can be defined as the interactions that take place among the different levels of government within a state. Usually, the concept is associated with states operating a federal system where the

Published on September 17, 2019

S. U. Ogbu is with School of Media and Communication, Pan Atlantic University, KM 52 Lekki-Epe Expressway, Ibeju-Lekki, Lagos-Nigeria. (email: sogbu@pau.edu.ng)

E. Fred is with Enugu State University of Science and Technology, Enugu-Nigeria relationships between the Federal, Central or National Government and the major sub-national unit (province, region or state) are formally spelt out in the constitution, and any re-arrangement must be through a constitutional amendment involving all the levels of government (Chukwuemeka \& Aniche, 2016).Thus, intergovernmental relations, involves the range of interactions among all types and levels of government. From extant literature, three major models of intergovernmental relations can be easily identified. These are the Partnership or OverlappingAuthority Model, the Principal/Agent or Inclusive-Authority Model and the Dual or Coordinate Authority Model (Benovertz, 1980; Wright, 1988). According to Nwokedi (2002), a full analysis of inter-governmental relations within a federal administrative system like Nigeria, must cover the following: Federal-State, Federal-State-Local, FederalLocal, Inter-State, State-Local and Inter-Local Relations. Such inter-governmental relations exist in areas of infrastructural development such as road construction and maintenance.

Roads construction in Nigerian has come a long way from 1914 when there was less than 3,600 kilometers of paved roads to a network currently in excess of 200,000 kilometers. Although no mean feat by any standard, expectations are, given the human and material resources at the disposal of the government, a much more robust road network should have been achieved in almost a century. Of the network developed so far, statistics indicate that the Federal Government is responsible for about 17 percent of road network. These roads are often referred to as trunk "A" roads and are mostly inter-states roads. State governments have been responsible for about 16 percent of paved roads, and these roads are mostly intra-state and city roads. On the other hand, local governments are responsible for 67 percent of the 200,000 kilometers of roads network in Nigeria, and these roads normally cut across communities in the rural areas (Igbikiowubo, 2008).

As stated earlier, the construction of road networks requires inter-governmental relations among the tiers of government. This research assessed the influence of intergovernmental relations between Federal and State governments on road maintenance in Nigeria. It focuses on three models of inter-governmental relations which include Partnership or Overlapping-Authority Model, the Principal/Agent or Inclusive-Authority Model and the Dual Functionalism or Coordinate Authority Model. However, though the study covers Nigeria, it concentrates on Enugu State. Hence, it is limited in its scope. 


\section{STATEMENT OF THE PROBLEM}

The existence of about 200,000 kilometers of roads in Nigeria is quite commendable. But the conditions of the roads leave much to be desired. For example, the link road between Anambra and Enugu States, the Onitsha-Enugu Express has been in a deplorable condition for more than a decade now. Frequent road users opine that the current situation of the road is largely attributed to conflicts between the tiers of government with regards to key functions and responsibilities.

The three tiers of government in Nigeria have not had a robust relationship over the years. Despite the setting up of several commissions and committees and recommendations proffered, role conflict still exists among the tiers of government. The blue print for road network in Nigeria has been developed in an uncoordinated way, with too much political influence over technical decisions on priority road projects. Moreover, the lack of an agreed strategic vision results to under-financing the maintenance of existing roads, their over-use, and the poor quality of roads which drive up the costs of domestic transportation.

These issues could be tackled through effective and efficient inter-governmental coordination. Sadly, in Nigeria, there are challenges facing the Federal-State intergovernmental relationship. For one, federal government agencies lack sufficient capacity to evaluate and manage performance, project and spending choices of states. On the other hand, states' executives view themselves as extremely autonomous, and thus are not under obligation to share information or participate in jointly executing projects. As ridiculous as this may be, unfortunately, the Constitution grants states the powers to engage in policy making and expenditure allocation independently and this boost the lack of cooperation. The multiplier effect of these conflicts can be seen in the poor state of road infrastructure in the country.

\section{OBJECTIVES OF THE STUdY}

Assessing the suitability of inter-governmental relations (Federal-State) models for the purpose of road maintenance in Nigeria is the broad objective of this study. Specifically, the study sought to:

1. Examine the effect of Partnership model of intergovernmental relations on road maintenance in Nigeria.

2. Determine the influence of Principal/Agent model of intergovernmental relations on road maintenance in Nigeria.

3. Evaluate the relevance of Functional Dualism model of intergovernmental relations on road maintenance in Nigeria.

\section{RESEARCH HYPOTHESES}

The following null-hypotheses were tested in the study:

(i) there is no significant effect of Partnership model of intergovernmental relations on road maintenance in Nigeria; (ii) Principal/agent model of intergovernmental relations does not have significant influence on road maintenance in Nigeria;

(iii) Functional dualism model of intergovernmental relations is not relevant to road maintenance in Nigeria.

\section{THEORETICAL FramewORK}

\section{The Theory of Federalism}

The theory of federalism was propounded by the father of contemporary federal theories- K.C. Wheare (1953). He defined federalism as "the method of dividing power so that general and regional governments are each within a sphere co-ordinate and independent". Federalism is thus, a system of government in which the indications of social, political and economic development are pursued by a coordinated effort of both central and other incorporated units of government (Osuagwu, 2013). Livingstonian definition of federalism holds the view that 'Federalism is not an absolute but a relative term; there is no identifiable point at which a society ceases to be unified and becomes diversified. All communities fall somewhere in a spectrum, this runs from what we may call a theoretically wholly integrated society at one extreme to a theoretically wholly diversified society at the other (Rhodes, 1983).

Further still, Wright (1995), citing the work of Bogdanor (1983) pointed out that other features of intergovernmental relations that set it apart from federalism include:

1. prominence of policy (rather than mainly legal) issues,

2. inclusion of all governmental entities-local units in addition to national-state (federal) relations,

3. importance of officials' attitudes and actions,

4. regular, continuous day to day interactions among officials and,

5. inclusion of all types of public officials- especially administrators in addition to elected officials (Wright, 1995).

The theory of Federalism is perfectly applicable to this study which examines the relationship between two level of government- Federal and State. However, it should be noted that the concept of Inter-Governmental Relations is not the same thing as Federalism. While no single definition of Federalism is generally accepted, it can be described as the contractual and legal status between the national (Central) government and the states, and to some extent between both the national and state governments and localities. On the other hand, Intergovernmental relations refer to the range of interactions among all types and levels of government.

\section{CONCEPTUAL FramewORK}

The conceptual framework of the study is centered on the key variables as well as relevant empirical studies carried out by other scholars.

\section{A. Concept of Intergovernmental Relations}

Intergovernmental relations (IGR) can be defined as the interactions that take place among the different levels of 
government within a state. Obi (2004) conceives intergovernmental relations to mean the complex patterns of interactions, co-operations and inter-dependence between two or more levels of government. IGR is further described as a plethora of formal and informal relationships and transactions that develop among levels of government within a nation-state. In Nigeria for instance, it refers to the interactions that exist among the Federal (Central or National) states and local governments, state and state interactions, state and local interactions or local and local interactions. All these put together refer to the pattern of intergovernmental relations.

An intergovernmental relations model, therefore, consists of facilitative systems and relationships that enable the units of government to participate effectively and carry out mandate so that governmental goals are achieved. This includes executive mechanisms, coordinating mechanisms, cooperative agreements, judicial and legislative mechanisms that all facilitate delivery by government machinery. Intergovernmental relations can thus be defined as the 'glue' that holds them together (Bello, 2014). In other words, it is the interactions, relationships and the conduct of officials between governmental activities. It seeks the achievement of common goals through mutual relationships between and across vertical and horizontal governmental arrangements, alignment and cohesion across all spheres of government. The aim of governmental relations therefore, is to enable governmental activities (primarily service delivery), through synergy, effectiveness and efficiency in delivering services, to sustain democracy and strengthen delivery capacity across all spheres of government for the common good (Isioma, 2010).

Basically, inter-governmental relations can be seen as relationship between all levels of governments within a political system. Inter-governmental relations in a federal System, like Nigeria, has taken an important dimension in recent time due largely to the attention now given to the importance of cooperative federalism. Nwokedi (2002) notes that inter-governmental relations cannot spell out all relations in a Federal system and that division of duties and responsibilities cannot be absolute. He also believes that inter-governmental relations refer to the whole array of activities intended to iron out the conflict inherent in a federal arrangement and that it stands on the premises that force, coercion or confrontation may be counterproductive.

\section{B. Characteristics of Intergovernmental Relations}

The dynamics of the Nigerian federation and the Nigerian Constitution make inter-governmental relations a political imperative. With over three hundred lingo-cultural groups, a population of over 180 million, 36 federating states and 774 Local Government, inter-governmental relations in Nigeria has been inexorable. Over the years, the pendulum of federal associations among groups has swung between centrifugal and centripetal forces as the different tiers of government sought to adjust their relationships within the federation. As Nigeria continued to use the framework of federalism to manage competing economic, social, cultural and religious interests, intergovernmental relations has become a necessary mechanism to promote cooperation, manage conflicts, respond to changing circumstance and deliver services more efficiently. Thus, IGR serves as a mechanism for managing conflict and improving the delivery of essential services to the citizenry.

The constitution defines the expenditure responsibilities of each level of government. While the federal government provides public services that are of national scope or importance, such as national defense, important expenditure responsibilities are assigned to the subnational levels of governments. Key local expenditure responsibilities include primary education and a host of traditional local government functions (such as operating local markets), while state governments play a key role in providing health care, secondary and tertiary education, and physical infrastructure (Boex \& Alm, 2002).

According to Chukwuemeka and Aniche (2016) institutions and processes of intergovernmental relations are geared towards;

(i) Promoting co-operation among governmental units

(ii) Recognizing and managing conflicts

(iii) Delivering services more efficiently

(iv) Responding to changing circumstances

In several cases, the Nigerian constitution assigns responsibilities for certain sectors to more than one level of government. For instance, higher education is a responsibility of both the federal government as well as state-level governments. Another example is that while the Nigerian Police Force is a federal agency, states are (nominally) assigned responsibility for state public order. Such joint assignment can lead to one of two extremes if the two levels of government fail to coordinate their efforts, namely either inadequate provision of certain government services or duplication of effort (Boex \& Alm, 2002).

\section{Models of Intergovernmental Relations}

Generally, three models of intergovernmental relations exist. These are the Partnership or Overlapping-Authority Model, the Principal/Agent or Inclusive-Authority Model and the Dual or Coordinate Authority Model (Benovertz, 1980).

Within the Partnership or Overlapping-Authority Model, the different levels of government are regarded as equals before the law. The Constitution and Parliament usually delineate and regulate the activities of all the levels of government. Consequently, both the powers and responsibilities of the various tiers of government could be added and subtracted from, over time. As a result of the coequal assumption of the model, state governments usually command considerable financial autonomy as they are given powers to tax their citizens and discretion on the nature, form and level of services they wish to provide.

In the partnership model too, there is an inbuilt cooperation and understanding among the various levels of government, such that the functions of one tier of government can be performed by another tier on its behalf. For instance, in recent times in Nigeria, states have been encouraged to rehabilitate or reconstruct federal roads with a view to being reimbursed by the federal government after proper evaluation of the job done. Additionally, as seen in Britain, where this model of intergovernmental relations is practiced, some services and functions which constitutionally belong to the central government are usually 
performed by the local governments on behalf of the central because the responsibilities in question are personal in nature and by extension performed close to or where the beneficiaries live. Such services are social welfare services, health and social security delivery, aspect of immigration control, among others. On the other hand, some local government services which are technically beyond the competence of the tier of government could be centrally performed on its behalf by the relevant field department of the central government ministry (Bello-Imam, 1996).

Within the Principal/Agents or Inclusive -Authority Model, a hierarchical view of the relationship between the Federal, State and Local Governments is presented. This contrasts sharply with the partnership model. Under this model, the states and local Governments are seen as means for locally administering centrally determined services. In real terms, the lower level of government under this model, that is, the local government, cannot be regarded as 'government' but as a form of local administration as it is in all practical senses a field agent of the central government. This means that within this model, services are deconcentrated and not devolved. Within this model too, local governments are grossly limited operationally by central rules and regulations. They may have some degree of local discretion but do not have any real independence of action. Within the model, the central government sees the local authority as spending money on its behalf as the expenditure of the lowest tier of government is subsumed in the annual budget of the central government. Consequently, it exercises checks and controls on local government activities (Ayoade, 1988; Bello-Imam, 1996).

A further consequence of the imprecise laws that govern relationships in this model is that, between the various tiers of government, the central government arrogates to itself the power to issue guidance and advice to the local governments on the way and manner they should execute their functions. The central government subsequently follows up the guidelines with inspection to ensure compliance. The implication of this is that distinction between functional spheres amongst the various tiers of government is tenuous. The French system of local government is a vivid example of this model. The nature of the colonial administration in Nigeria as it relates to local governance, and central government-local government relations during the first military regime in Nigeria between 1966 and 1976 are also examples of the practice of this model in Nigeria (Bamgbose, 2008).

The Functional Dualism or Coordinate-Authority Model is the model of intergovernmental relations in which the various levels of government within a nation-state are given functional prerogative in the delivery of certain critical services as measured by their administrative or technical competence. Within this model, functional autonomy is usually emphasized. An example of this is where the various levels of government have concurrent responsibility in the discharge or provision of health, educational and agricultural services. This model is an opposite pole to the Inclusive-Authority Model. The model aims at the coordination of the activities of all the units in the overall interest of the polity and the society. All the units, as per this model, are to work in accordance with the basic spirit of the constitution and established conventions of the land (Egomwan, 1984).

In a sense, therefore, the functional dualism model attempts to integrate both the elements of the partnership and the principal/agent models of intergovernmental relations. The significant distinguishing element is the emphasis on functional competence within the concurrent responsibility arrangement.

In conclusion, it should be noted that whatever model of intergovernmental relations exists in a nation-state does not necessarily make the sub-national or local governments independent and sovereign units in themselves. This is because local governments are only infra-sovereign units of government, administratively decentralized by the sovereign nation-state. Being statutory creatures of the central government, they are inevitably subjected to various administrative supervisions by the central government (Humes \& Martin, 1961). The totality of these supervisory relationships constitute the subject of intergovernmental relations which is most often misconstrued to be 'controls' by the higher tiers of government.

\section{Situation of Road Transportation in Nigeria}

The Nigerian road network comprises federal roads, state roads and local roads (Olatunji \& Diugwu, 2013). The Nigerian transport system (transport modes) consists of: $198,000 \mathrm{~km}$ of Roads, 3,500 km of Railways, 8,600 km of Inland Waterways and 22 Airports (Chidoka, 2011). The overall efficiency and effectiveness of the transport system depends on the development of these modes and their interfacing/integration (Draft National Transport policy, 2010). Budgetary allocation to the transport system from 1999 to 2018 shows that road infrastructure got a larger share compared with the other modes of transportation. The state of road infrastructure in Nigeria despite the huge allocations of funds to it has become a matter of great concern and interests to citizens and researchers.

The failure in maintaining the roads can easily be identified as one of the major factors leading to accidents, increasing cost of transportation and stagnation in the growth of the nation's economy. Okigbo (2012), from his study on the causes of failure of Nigerian highways, lists some of the factors as: poor design and construction, poor maintenance of already built highways, use of low quality materials in construction, poor workmanship, poor supervision of construction work and the plying of heavy traffic on roads they were not meant for.

TABLE I: BUDGETARY ALLOCATION TO ROAD INFRASTRUCTURE 1999-

\begin{tabular}{lc}
\hline & 2018 \\
\hline \hline Year & Allocation (billion $)$ \\
\hline 1999 & $9,583,000,000.00$ \\
\hline 2000 & $36,947,326,332.00$ \\
\hline 2001 & $66,867,990,000.00$ \\
\hline 2002 & $70,002,773,000.00$ \\
\hline 2003 & $55,547,940,000.00$ \\
\hline 2004 & $42,607,064,300.00$ \\
\hline 2005 & $70,490,562,710.00$ \\
\hline 2006 & $67,734,363,765.00$ \\
\hline 2007 & $716,126,211.00$ \\
\hline 2008 & $67,982,651,723.00$ \\
\hline 2009 & $198,618,000,000.00$ \\
\hline 2010 & $210,773,218,922.00$ \\
\hline 2011 & $128,966,108,230.00$ \\
\hline
\end{tabular}




\begin{tabular}{ll}
\hline \hline 2012 & $133,000,000,000.00$ \\
\hline 2013 & $183,500,000,000.00$ \\
\hline 2014 & $133,726,558,986.00$ \\
\hline 2015 & $139,579,312,175.00$ \\
\hline 2016 & $136,652,935,580.00$ \\
\hline 2017 & $279,940,000,000.00$ \\
\hline 2018 & $208,296,467,790.00$ \\
\hline \hline
\end{tabular}

Source: Budget office of Nigeria, Federal Ministry of Finance

Road networks grew from $6,500 \mathrm{~km}$ in 1960 to 10,000 $\mathrm{km}$ in 1970 and to $29,000 \mathrm{~km}$ in 1980 (Ebenezar-Uzor, 2011). In 1990 Nigeria had 108, 000 kilometers of roads out of which 30,000 kilometers were paved, 25,000 kilometers were gravel, and the rest were unimproved earth carrying 95 percent of all the nation's goods and passengers, the roads constituted the most important element in the transportation network. The estimated current total road network is now over 198, 000 kilometres (Chidoka, 2011).

The responsibility for planning, developing and maintaining the nation's transport infrastructure is divided among the three tiers of Government. Intra-state roads are the responsibility of state governments, while the local governments are required to cater for intra-urban and rural feeder roads, which account for about $66 \%$ of the existing road network. The federal government is responsible for the national highways which constitute only $17 \%$ of the existing road network. In addition, the federal government through its agencies is also responsible for financing inland waterways/river ports, sea ports, railways, airports and pipelines (Draft National Transport Policy, 2010).

As it stands today, seventeen percent $(17 \%)$ of the total road network in Nigeria is owned and managed by the federal government (trunk A roads); another seventeen percent $(17 \%)$ of the $198,000 \mathrm{~km}$ road network is owned and managed by the thirty-six states (trunk B roads) while the remaining sixty-six percent $(66 \%)$ is owned and managed by the seven hundred and seventy-four (774) local government areas (trunk C roads) of Nigeria (Muhammad, 2014).

\section{EMPIRICAL REVIEW}

A study conducted by Osuagwu (2013), dealt on intergovernmental relations and the performance of local government in Imo State, Nigeria. The research was carried out through the use of secondary data collected from the review of textbooks, journals, magazines, internet materials, etc., while the primary data collection was through questionnaires administered to 270 respondents, made up of thirty staff from each local government council drawn from nine (9) local governments, three of which were selected from each senatorial zone. The study found out that intergovernmental relations ensure the effective and efficient utilization of human and material resources among the different levels of government. It recommended that the irregularities found in the delivery of essential services can be tackled by having elected officials serve in the local governments (as opposed to selected or appointed officers), practicing true federalism, applying the principle of rule of law, constitutional specification of the areas of jurisdiction for each of the levels of government and granting local governments autonomy to operate freely within the scope of their constitutional responsibilities.
Another study by Chukwuemeka and Aniche (2016) examined inter-governmental relation and the performance of local government in Nigeria. The study adopted the survey design and descriptive research method. Data was collected using questionnaire and focus group discussions (FGD). Secondary data was generated from government records and Central Bank of Nigeria. The findings revealed among others things that intergovernmental relations, have to an extent, helped to reduce tension among the three tiers of government in Nigeria despite the fact that the imperfection of 1999 constitution has hampered fiscal relations among the three tiers of government in Nigeria. The study recommended among other things that effort should be made to ensure that all tiers of government should adhere to fiscal transparency, accountability and constitutional provisions on fiscal relations.

Farouq, Anwar, Baba, Labbo, and Aliyu (2017) examined the road maintenance management of Kano metropolitan roads and the possible ways of improving it. The authors examined the types of road defect on Kano metropolitan roads, the factors that contribute to the road defects, the road user's satisfaction on the maintenance works carried out by Kano road maintenance management agency (KARMA) and analyzed the problems on road defect reporting system in KARMA. The study was conducted using questionnaires, interviews and maintenance reports available at the KARMA. For data collection, questionnaires administered on staff of KARMA, Kano Urban Planning and Development Authority (KNUPDA), Federal Ministry of Works (FMW) and the road users. Data collected were analyzed using SPSS and Average Index. From the study, the types of road defect found on Kano metropolitan roads are potholes, patching and utility cut, patching/reinstatement of utility openings (electricity, water, telecommunication etc.) and edge cracks. The factors identified as contributing to the road defects are structural failure (due to poor design and construction), inadequate maintenance policy and standards, and the traffic load/volume on the roads. Overall, the road user's satisfaction on the maintenance works carried out by KARMA are came out negative while the road defect reporting system and documentation in KARMA was adjudged 'unsatisfactory'.

Onwughalu, Obiorah and Ishaka (2018) examined the nature of the Nigerian State and challenges of its constitutional provisions skewed in favor of the federal government as evidenced in the Exclusive Legislative List. It argues that this present arrangement impedes the pace of development in the country. The study was qualitative in nature and gathered data through secondary sources that were content analyzed using the Structural-Functional framework. Findings from the study revealed that federal ascendancy defines the nature of intergovernmental relations in Nigeria, therefore, the observable functional cooperation is only a vertical pattern of relationship between the federal and state governments on the one hand, and amongst the federal, state and local governments on the other. It found out that in spite of the existence of informal structures like Nigeria Governors' Forum (NGF), Conference of Speakers of State Legislatures of Nigeria (CSSLN) and Association of Local Government of Nigeria (ALGON), etc, that should provide platforms for horizontal partnerships and co- 
operations between or amongst states and between or amongst local government councils, there is no evidence of such functional collaborations in several spheres which indicates a missing link in the inward approach to development and integration, especially in the face of challenges posed by the defects in the 1999 constitution.

\section{RESEARCH METHODOLOGY}

This study adopted the cross-sectional survey research design. The area chosen for the study is Enugu State, located in the South-East geo-political zone of Nigeria. The population of the study is comprised of staff of the federal and state ministry of works as well as staff of the Federal Road Maintenance Agency (FERMA). Thirty respondents were conveniently selected for the study-10 from Federal Ministry of Works (Enugu Office); 10 from Enugu State Ministry of Works; and 10 from the FERMA (Enugu Office).

Questionnaires were used to source primary data from the respondents. The questionnaire items measured the extent to which the respondents understood inter-governmental relations, as they were conceptualized in the literature review, and the effect of those relations on road maintenance in Nigeria. The questionnaire was pilot tested and rated as reliable after being subjected to a Cronbach Alpha test which gave a result of 72 percent. The ease of access to the respondents allowed for a personal administration of the instrument. The data obtained were tested statistically using multiple regression analysis.

\section{Data PRESENTAtion AND ANALYSIS}

As stated earlier, the personal administration of the questionnaire by the researcher ensured hundred percent return rates thereby eliminating non-return bias. Table II shows the summarized responses towards each category of the questionnaire items.

TABLE II: RESPONSES ON FEDERAL-STATE INTERGOVERNMENTAL RELATIONSHIP AND ROAD MAINTENANCE

\begin{tabular}{|c|c|c|c|c|c|c|}
\hline & Statement & SA & A & $\mathrm{U}$ & $\mathrm{D}$ & SD \\
\hline \multicolumn{7}{|c|}{ Partnership Model } \\
\hline 1 & $\begin{array}{l}\text { The state is } \\
\text { empowered } \\
\text { to maintain } \\
\text { roads on } \\
\text { behalf of } \\
\text { the federal } \\
\text { government }\end{array}$ & $16(53.3 \%)$ & $7(23.3 \%)$ & $2(6.7 \%)$ & $5(16.7 \%)$ & $0(0 \%)$ \\
\hline 2 & $\begin{array}{l}\text { The Federal } \\
\text { Governmen } \\
\text { t builds the } \\
\text { road while } \\
\text { the state } \\
\text { government } \\
\text { maintains it }\end{array}$ & $15(50.0 \%)$ & $9(30.0 \%)$ & $3(10.0 \%)$ & $3(10.0 \%)$ & $0(0 \%)$ \\
\hline \multicolumn{7}{|c|}{ Principal/Agent model } \\
\hline 3 & $\begin{array}{l}\text { The federal } \\
\text { government } \\
\text { is obligated } \\
\text { to make } \\
\text { refunds to } \\
\text { the state } \\
\text { when it has } \\
\text { fixed } \\
\text { federal }\end{array}$ & $16(53.3 \%)$ & $6(20.0 \%)$ & $5(16.7 \%)$ & $3(10.0 \%)$ & $0(0 \%)$ \\
\hline
\end{tabular}

\begin{tabular}{|c|c|c|c|c|c|c|}
\hline & roads. & & & & & \\
\hline \multirow[t]{2}{*}{4} & $\begin{array}{l}\text { The state } \\
\text { government } \\
\text { adheres to } \\
\text { the federal } \\
\text { government } \\
\text { specificatio } \\
\text { n for road } \\
\text { projects. }\end{array}$ & $10(33.3 \%)$ & $11(36.7 \%)$ & $6(20.0 \%)$ & $3(10.0 \%)$ & $0(0 \%)$ \\
\hline & \multicolumn{6}{|c|}{ Functional Dualism model } \\
\hline 5 & $\begin{array}{l}\text { Coordinatio } \\
\mathrm{n} \text { between } \\
\text { the federal } \\
\text { and state } \\
\text { government } \\
\text { ensures that } \\
\text { there is no } \\
\text { conflict of } \\
\text { interest in } \\
\text { road } \\
\text { maintenanc } \\
\text { e projects. }\end{array}$ & $12(40.0 \%)$ & $13(43.3 \%)$ & $2(6.7 \%)$ & $3(10.0 \%)$ & $0(0 \%)$ \\
\hline 6 & $\begin{array}{l}\text { When } \\
\text { conflict } \\
\text { arises, the } \\
\text { interest of } \\
\text { the federal } \\
\text { government } \\
\text { takes } \\
\text { precedence } \\
\text { over that of } \\
\text { the state. }\end{array}$ & $15(50.0 \%)$ & $13(43.3 \%)$ & $1(3.3 \%)$ & $1(3.3 \%)$ & $0(0 \%)$ \\
\hline \multicolumn{7}{|c|}{ Road Maintenance } \\
\hline 7 & $\begin{array}{l}\text { Enugu State } \\
\text { government } \\
\text { maintains } \\
\text { federal } \\
\text { roads }\end{array}$ & $6(20.0 \%)$ & $17(56.7 \%)$ & $4(13.3 \%)$ & $3(10.0 \%)$ & $0(0 \%)$ \\
\hline 8 & $\begin{array}{l}\text { The state } \\
\text { government } \\
\text { has } \\
\text { adequate } \\
\text { funds to } \\
\text { maintain } \\
\text { federal } \\
\text { roads in the } \\
\text { State }\end{array}$ & $10(33.3 \%)$ & $17(56.7 \%)$ & $2(6.7 \%)$ & $1(3.3 \%)$ & $0(0 \%)$ \\
\hline
\end{tabular}

Table II presents the responses on Federal-State intergovernmental relationship and road maintenance. The result of statement 1 and 2 shows the opinion of respondents on the partnership model of intergovernmental relationship. 16 respondents $(53.3 \%)$ strongly agreed that the state is empowered to maintain roads on behalf of the federal government; 7 (23.3\%) of the participants agreed; 2 (6.7\%) were undecided on this; $5(16.7 \%)$ disagreed and none of the respondents $(0 \%)$ strongly disagreed. Still on the partnership model, 15 respondents $(50 \%)$ strongly agreed that the Federal Government builds the road while the state government maintains it; $9(30 \%)$ of the participants agreed; $3(10 \%)$ were undecided on this; $3(10 \%)$ disagreed and none of the respondents $(0 \%)$ strongly disagreed.

The result of statement 3 and 4 in Table II shows the opinion of respondents on principal/agent model of intergovernmental relationship. 16 respondents (53.3\%) strongly agreed that the federal government is obligated to make refunds to the state when it has fixed federal roads; 6 $(20 \%)$ of the participants agreed; $5(16.7 \%)$ were undecided on this; $3(10 \%)$ disagreed and none of the respondents $(0 \%)$ strongly disagreed. Still on the principal/agent model, 10 respondents $(33.3 \%)$ strongly agreed that the state 
government adheres to the federal government specification for road projects; 11 (36.7\%) of the participants agreed; 6 $(20 \%)$ were undecided on this; $3(10 \%)$ disagreed and none of the respondents $(0 \%)$ strongly disagreed.

The result of statement 5 and 6 in Table II shows the opinion of respondents on functional dualism model of intergovernmental relationship. 12 respondents $(40 \%)$ strongly agreed that coordination between the federal and state government ensures that there is no conflict of interest in road maintenance projects; $13(43.3 \%)$ of the participants agreed; 2 (6.7\%) were undecided on this; 3 (10\%) disagreed and none of the respondents $(0 \%)$ strongly disagreed. Still on the functional dualism model, 15 respondents $(50 \%)$ strongly agreed that when conflict arises, the interest of the federal government takes precedence over that of the state; $13(43.3 \%)$ of the participants agreed; 1 (3.3\%) was undecided on this; 1 (3.3\%) disagreed and none of the respondents $(0 \%)$ strongly disagreed.

The result of statement 7 and 8 in Table II shows the opinion of respondents on road maintenance in Enugu State, Nigeria. 6 respondents $(20 \%)$ strongly agreed that Enugu State government maintains federal roads; 17 (56.7\%) of the participants agreed; 4 (13.3\%) were undecided on this; 3 $(10 \%)$ disagreed and none of the respondents $(0 \%)$ strongly disagreed. When asked if the state government has adequate funds to maintain federal roads in the State, 10 respondents (33.3\%) strongly agreed; 17 (56.7\%) agreed; 2 (6.7\%) were undecided on this; $1(3.3 \%)$ disagreed and none of the respondents $(0 \%)$ strongly disagreed.

\section{Hypotheses Testing And Discussion of Results}

TABLE III: MULTIPLE REGRESSION ANALYSIS OF THE INFLUENCE OF

FEDERAL-STATE INTERGOVERNMENTAL RELATIONSHIP ON ROAD MAINTENANCE

\begin{tabular}{|c|c|c|c|c|c|c|}
\hline \multirow{2}{*}{$\begin{array}{c}\text { Model } \\
\text { Summar } \\
\mathbf{y}\end{array}$} & $\mathbf{R}$ & $\begin{array}{c}\mathbf{R} \\
\text { Squar } \\
\mathbf{e}\end{array}$ & $\begin{array}{c}\text { Adjust } \\
\text { ed R } \\
\text { Square }\end{array}$ & Std. Error & & \\
\hline & 0.743 & 0.552 & 0.498 & 1.237 & & \\
\hline \multirow{4}{*}{ ANOVA } & & $\begin{array}{c}\begin{array}{c}\text { Sum } \\
\text { of } \\
\text { Squar } \\
\text { es }\end{array} \\
\end{array}$ & df & $\begin{array}{c}\text { Mean } \\
\text { Square }\end{array}$ & $\mathbf{F}$ & Sig. \\
\hline & $\begin{array}{l}\text { Regressi } \\
\text { on }\end{array}$ & 47.185 & 3 & 15.728 & $\begin{array}{c}10.2 \\
76\end{array}$ & $\begin{array}{l}.00 \\
0^{\mathrm{b}}\end{array}$ \\
\hline & Residual & 38.263 & 25 & 1.531 & & \\
\hline & Total & 85.448 & 28 & & & \\
\hline \multirow{6}{*}{$\begin{array}{l}\text { Coefficie } \\
\text { nts }\end{array}$} & & \multicolumn{2}{|c|}{$\begin{array}{l}\text { Unstandardized } \\
\text { Coefficients }\end{array}$} & $\begin{array}{l}\text { Standardi } \\
\text { zed } \\
\text { Coefficien } \\
\text { ts }\end{array}$ & & \\
\hline & & B & $\begin{array}{c}\text { Std. } \\
\text { Error }\end{array}$ & Beta & $\mathbf{T}$ & Sig \\
\hline & $\begin{array}{l}\text { (Constan } \\
\text { t) }\end{array}$ & 3.207 & 2.366 & & $\begin{array}{c}1.35 \\
5\end{array}$ & $\begin{array}{c}.18 \\
7\end{array}$ \\
\hline & $\begin{array}{l}\text { Partners } \\
\text { hip }\end{array}$ & .360 & .132 & .429 & $\begin{array}{c}2.72 \\
0 \\
\end{array}$ & $\begin{array}{c}.01 \\
2 \\
\end{array}$ \\
\hline & Principal & -.004 & .181 & -.004 & -.024 & $\begin{array}{c}.98 \\
1 \\
\end{array}$ \\
\hline & $\begin{array}{l}\text { Function } \\
\text { al } \\
\text { Dualism }\end{array}$ & .475 & .172 & .436 & $\begin{array}{c}2.76 \\
4\end{array}$ & $\begin{array}{c}.01 \\
1\end{array}$ \\
\hline
\end{tabular}

a. Dependent Variable: Road Maintenance

b. Predictors: (Constant), Functional Dualism, Principal, Partnership Source: SPSS Output, 2019

Table III shows the influence of federal-state intergovernmental relationship on road maintenance. The model summary reveals that the relationship between both variables is 74.3 percent (as seen in the $R$ column). The $R^{2}$ value (0.552) signifies that up to 55.2 percent of road maintenance is determined by intergovernmental relationship when other variables are held constant. The Ftest $(10.276, p<0.05)$ of the relationship in Table III indicates that the overall prediction of the independent variable to the dependent variable is statistically significant, therefore, the regression model provides sufficient evidence to conclude that federal-state intergovernmental relationship significantly influence road maintenance in Nigeria.

The coefficients section of the table provides the necessary information on the strength of each model of intergovernmental relationship. From the table it can be seen that two of the models (Partnership and Functional Dualism) significantly affect road maintenance in Nigeria as seen from their $\mathrm{p}$-value $(\mathrm{p}<0.05)$. On the other hand, Principal/Agent model does not significantly influence road maintenance $(p>0.05 ; t=-0.2)$. Interestingly, between the significant models of intergovernmental relationship, Functional Dualism wields a stronger influence on road maintenance than Partnership model as noted from their beta coefficients (ßPartnership= 42.9 percent; BFunctional Dualism $=43.6$ percent). The result of the regression requires that null hypotheses one and three (Hol and Ho3) be rejected. On the other hand, null hypotheses two (Ho2) is accepted.

From the results of the hypotheses testing, it is seen that partnership model and functional dualism model of intergovernmental relations significantly influence road maintenance in Nigeria. However, the results show that principal/agent model of intergovernmental relations does not significantly influence road maintenance in Nigeria. This outcome could be attributed to the nature of the principles that define the various models of intergovernmental relationships. As explained in the literature, within the partnership model, the federal and state governments are viewed as partners when carrying out key governmental functions such as road maintenance. This form of relationship gives both tiers of government a sense of responsibility towards this service, thus giving credence to the position of the theory of federalism, which insists on the clear definition of both the legal status and the contractual relations between the central government and the federating states.

Additionally, road maintenance is efficiently performed in the functional dualism model of intergovernmental relations. This is because both levels of government may have functional competencies in the delivery of different but complimentary critical services. Given these levels of competences, the federal and state government can partner effectively in maintaining roads in Nigeria. However, the roles and functions of each level of government must be clearly spelt out to avoid ambiguities and unnecessary conflicts during implementation.

In general, the poor condition of roads in Nigeria can be attributed to the form of intergovernmental relation mainly adopted in the country. Onwughalu, Obiorah and Ishaka (2018) study revealed that the observable functional cooperation in Nigeria is only a vertical pattern of relationship between the federal and state governments. This 
vertical pattern of relationship is synonymous with the Principal/Agent model of intergovernmental relation which has proven to be ineffective in road maintenance.

\section{CONCLUSION AND RECOMMENDATIONS}

This study has given credence to the effectiveness of intergovernmental relation on provision of services to the Nigerian citizenry with specific emphasis on road maintenance. Though several forms or model of intergovernmental relations exist, it has been established that the partnership and functional dualism models exert significant influence on road maintenance in the country. The study has further proven that when different levels of government seek to perform functions aimed at improving the citizens' quality of life, cooperation works better than competition. Federal and state governments stand to achieve more when their relationship takes a horizontal form (Partnership/Dual functionalism) rather than vertical form (Principal-Agent model). Theoretically, the research findings are in alignment with the postulations of the theory of federalism and the outcome of the regression analysis favors the partnership model of intergovernmental relationship. From the analysis of the results in this study, the following recommendations are put forward:

1. All levels of government should strive to adopt the partnership or functional dualism model of intergovernmental relations. This would enable them to cooperate rather than compete, knowing that they are all partners in national progress.

2. States should endeavor to be honest and transparent when reporting the cost incurred for road maintenance. This would build trust and cordial relationship between the federal and state government.

3. When states submit expenditures incurred on the maintenance of federal roads, the federal government should reimburse them without long delays and bureaucratic bottlenecks.

\section{REFERENCES}

Ayoade, J.A.A. (1980). Inter-governmental relations in Nigeria. Quarterly Journal of Administration, 16(2), 119-132.

Bamgbose, J. A. (2008). Intergovernmental relations and political opposition in-Nigeria's Fourth Republic - (1999-2004). Ozean Journal of Social Sciences, 1(1), 75-89.

Bello-Imam, I.B. (1996). Local Governmgnt in Nigeria: Evolving a third tier of government. Ibadan: Heinemmann Educational Books (Nigeria) PLC.

Bello, M. L. (2014). Intergovernmental relations in Nigeria: An assessment of its practice at the local government level. Journal of Poverty, Investment and Development, 4, 66-76.
Benovetz, J. (1980). Federalism and intergovernmental relations: The American-Experience. Quarterly Journal Administration, 14(3), 141156.

Boex, J. \& Alm, J. (2002). An overview of intergovernmental fiscal relations and subnational public finance in Nigeria. International Studies Program, Andrew Young School of Policy Studies Working Paper 02-1.

Budget Office of Nigeria, Federal Ministry of Works, 1999 to 2018. Twitter (a) budgIT, You Can Request for Budget Files.

Chidoka, O. (2011). Successes and challenges of a lead agency and the multisectoral nature of road safety. Nigeria: Federal Road Safety Corps.

Chukwuemeka, E. \& Aniche, I. (2016). Inter-governmental relations and the performance of local government in Nigeria: Diagnosing the elephantine problems. Arabian Journal of Business and Management Review (Oman Chapter) 6(3), 17-36.

Ebenezar-Uzor, S. (2011). Nigerian Road Infrastructure: Options for Transformation. Zenith Economic Quarterly, Application of Zenith Bank Plc, 6(1).

Egomwan, J.A. (1984). Principles and practice of local government in Nigeria: An insight into the problems of public policy formulation and implementation. Benin City: SMO Aka and Brothers Press.

Farouq, M. M., Anwar, F. H., Baba, Z. B., Labbo, M. S., \& Aliyu, D. S. (2017). Road maintenance management in Kano State, Nigeria: Case study of Kano Metropolitan. Journal of Mechanical and Civil Engineering, 14 (3), 50-62.

Humes, S. \& Martin, E.M. (1961). The structure of local government throughout the world. The Hague: Nijhoff Press.

Igbikiowubo, H. (2008). Nigeria: History, structure of the roads system. Retrieved from: https://allafrica.com/stories/200806240144.html

Isioma, U.I. (2010) Strengthening intergovernmental relations for improved service delivery in South Africa: Issues for consideration. Journal of US-China Public Administration, 7(1), 51-57.

Muhammad, M. H. (2014). An evaluation of government provision and maintenance of infrastructures in Nigeria: the case of road transport infrastructure. M.Sc. Thesis of the Department of Economics, Faculty of Social Sciences, Ahmadu Bello University, Zaria, Nigeria.

National Transport Policy Paper, 2010.

Nwokedi, R. C. (2002). Power sharing in Nigeria federation. Enugu: Snaap Press.

Obi, V. O. A. (2004). Modern local government practice in Nigeria. Enugu: Cecta (Nig) Limited.

Okigbo, N. (2012). Causes of highway failures in Nigeria. International Journal of Engineering Science and Technology, 4(11), 4695-4703.

Olamilekan, A. (n.d). The impact of inter-governmental relations on local government administration in Nigeria: the study of Abuja Municipal Area Council, Abuja.

Olatunji, A. \& Diugwu, I. A. (2013). A project management perspective to the management of federal roads in Nigeria: A case study of MinnaBida Road. Journal of Finance and Economics. 1(4), 54-61.

Onwughalu, V. C., Obiorah, C. \& Ishaka, D. (2018). Intergovernmental relations and development in Nigeria: The missing link. A Paper Presented at the 31st National Conference of the Nigerian Political Science Association (NPSA), held at the International Conference Centre, Abakaliki, Ebonyi State, March 26 - 29.

Osuagwu, R. N. (2013). Inter-governmental relations and the performance of local governments in Imo State, Nigeria 2005 - 2013.Master of Science project submitted to University of Nigeria, Nsukka (UNN).

Rhodes, R. (1983). Control and power in central-local government relations. Aldershot: Gower Publishing Company

Wheare, K.C. (1953). Federal government. 3rd Ed. London: OUP.

Wright, D.S. (1988). Understanding intergovernmental relations. California: Books/ColePublishing Company.

Wright, D.S. (1995). Democracy and federalism in the United States of America: Inter-governmental patterns, politics and perspective. In: Aborisade, O. and -Mundt, R. (Eds.), Local Government in Nigeria and the United States: Learning from Comparison. Ibadan: Samadex. 